\title{
An Investigation of High-Performance Self Compacting Concrete under Flexural Loading
}

\author{
Theerthananda M P ${ }^{1, *}$, P C Srinivasa ${ }^{1}, \mathbf{G}$ M Naveen ${ }^{2}$ \\ ${ }^{1}$ Department of Civil Engineering, Government Engineering College, Kushalnagar, India \\ ${ }^{2}$ Department of Civil Engineering, Government Engineering College, Chamarjanagar, India
}

Received October 20, 2020; Revised November 25, 2020; Accepted December 30, 2020

\section{Cite This Paper in the following Citation Styles}

(a): [1] Theerthananda M P, P C Srinivasa, G M Naveen, "An Investigation of High-Performance Self Compacting Concrete under Flexural Loading," Civil Engineering and Architecture, Vol. 8, No. 6, pp. 1414 - 1418, 2020. DOI: 10.13189/cea.2020.080624.

(b): Theerthananda M P, P C Srinivasa, G M Naveen (2020). An Investigation of High-Performance Self Compacting Concrete under Flexural Loading. Civil Engineering and Architecture, 8(6), 1414 - $1418 . \quad$ DOI: 10.13189/cea.2020.080624.

Copyright $\odot 2020$ by authors, all rights reserved. Authors agree that this article remains permanently open access under the terms of the Creative Commons Attribution License 4.0 International License

\begin{abstract}
To shorten construction period, to assure compaction in the structure especially in confined zones where vibrating compaction is difficult and to eliminate noise due to vibration effective especially at concrete products plants SCC is developed in practice. Also, SCC is applied to tunnel lining for preventing the cold joint Self-compacting concrete has been used. Currently, the main reasons for the employment of self-compacting concrete can be summarized as follows: developing alternate binders that are environment-friendly and contribute to sustainable management. The properties of SCC in fresh concrete stage cost reduced time and substantial effective construction expertise in Special concrete of High-Performance Self Compacting Concrete (HPSCC) properties, the present work as major aspects like Effect of fibers with Fly ash on Fresh concrete properties and Behavior of polypropylene fibers Specimens under split tensile \& Flexural loading. The first parts of the work have been focused on the effect of polypropylene fibers on Fresh and harden concrete of Ultimate Strength with replacement of varying Polypropylene fibers by $0 \%$ to $1.5 \%$ at the interval of 0.5 and next part of the work focusing the behavior of fiber under Flexural loading. The results obtained from this work are expected to be useful in determining behavior of SCC with polypropylene fiber Specimens. This will help the designing SCC specimens to resist Flexural loading.
\end{abstract}

Keywords Cement, Fly Ash, Polypropylene Fibers, Splitting Tensile Strength, Flexural Loading

\section{Introduction}

High Performance Self Compacting Concrete (HPSCC) is the one which ability to Flow, good viscosity, segregation resistance and passing ability. The supplementary cementitious materials like fly ash are used to improve the alkali-aggregate reactivity with the correct dosage of superplastizers mix. Superplastizers are used to avoid segregation in concrete mix and have a good and high slump. Some earlier research shows that viscosity modifying admixture to enhance stability and rheological properties improve by fly ash. Supplementary Cementitious materials also react differently with different cement. Heat of hydration of the cement by using fly ash in high performance SCC reduces cracking of concrete. In this work up to $60 \%$ of the Portland cement is replaced by fly ash. The application of the high-performance SCC is wider range used to constructions area where required high strength and particular property of concrete is improved.

Fibers like glass, nylon, coir, steel, asbestos and polypropylene(PP) etc. have been used in the previous. Out of these polypropylene fibers best performance to enhanced the properties of flexural strength $[1,2]$. Steel fibers also better improve the toughness and flexural strength, but it damages by corrosion and increased densities are the one of the drawbacks. Due to this 
polypropylene fiber is used in this study [3].

The workability of the High-Performance SCC is excellent because of using fly ash in this present work. The outlines of the article evaluating the

Performance of High-Performance SCC in both fresh and harden state characteristics enhance the performance [4,5]. The behaviours of High-performance SCC in flexure are study in the present work to know the behaviours of Fly ash and fiber combination in the current situation in the concrete industries.

Table 1. Properties of Cement

\begin{tabular}{|c|c|}
\hline Standard consistency (\%) & 32 \\
\hline Initial setting time (min) & 48 \\
\hline Final setting time (min) & 538 \\
\hline Fineness of cement $\left(\mathrm{m}^{2} / \mathrm{kg}, \mathrm{min}\right)$ & 289 \\
\hline Specific gravity of cement & 3.15 \\
\hline Compressive Strength of cubes: & \\
3 Days $\left(\mathrm{N} / \mathrm{mm}^{2}\right)$ & 28.6 \\
7 Days $\left(\mathrm{N} / \mathrm{mm}^{2}\right)$ & 39.7 \\
28 Days $\left(\mathrm{N} / \mathrm{mm}^{2}\right)$ & 54.6 \\
\hline
\end{tabular}

Table 2. Properties of Fly ash

\begin{tabular}{|c|c|}
\hline Type & II \\
\hline Specific gravity & 2.28 \\
\hline Water content (\%) & 0.05 \\
\hline Fineness modulus & 4.58 \\
\hline Fineness (m2 $/ \mathrm{kg}, \mathrm{min})$ & 245 \\
\hline
\end{tabular}

Table 3. Properties of M- Sand

\begin{tabular}{|c|c|}
\hline Specific gravity & 2.64 \\
\hline Density $(\mathrm{kN} / \mathrm{m} 3)$ & 16.2 \\
\hline Water content $(\%)$ & 0.5 \\
\hline Fineness modulus & 2.8 \\
\hline
\end{tabular}

\section{Earlier Works}

From the review of earlier investigations related to mechanical properties of SCC with fly ash under Flexural loading with increased performance and function having been reported $[6,7]$ and some results show the behaviours of elements have been tabulated on the researchers of such studies. No information has been available on the response of High-performance SCC with fly ash \& polypropylene elements subjected to Flexural loading.

\section{Materials and its Proportional Properties}

\subsection{Materials}

The following materials are used,

$\begin{aligned} \text { I } & \text { Cement } \\ \text { ii } & \text { Fly ash } \\ \text { iii } & \text { Fine aggregate } \\ \text { iv } & \text { Coarse Aggregate } \\ \text { v } & \text { Polypropylene } \\ \text { vi } & \text { Water }\end{aligned}$

i Cement: Ordinary Portland cement conforming to IS: 12269-2013, which was stored in a cool and dry place, was used $[8,9]$ and physical properties of cement shown in Table 1.

ii Fly ash: The fly ash Class F (Type-II) used to replace cement was obtained from Thermal power plant, Raichur and tested [10] the properties shown in Table 2.

iii Fine aggregate: M-Sand used in the High-performance SCC is taken from near quarry. This M- sand is totally free from all impurity and organic matters and tested [11], the properties shown in Table 3.

iv Coarse aggregate: $20 \mathrm{~mm}$ down aggregate used in the High-Performance SCC is taken from near quarry. This aggregate is totally free from surface moisture and all impurity with gradation and tested [12] and their properties shown in Table 4.

v Polypropylene (PP): Polypropylene with density of $0.92 \mathrm{~g} / \mathrm{cm}^{3}$ are used in the present work.

vi Water: The mixing water should be potable, fresh \& clean. Ordinary potable water was used for mixing

\subsection{Mix Proportion}

Table 4. Properties of coarse Aggregate

\begin{tabular}{|c|c|}
\hline Specific gravity & 2.68 \\
\hline Density $\left(\mathrm{kN} / \mathrm{m}^{3}\right)$ & 17.3 \\
\hline Water content $(\%)$ & 1 \\
\hline Fineness modulus & 6 \\
\hline
\end{tabular}

The mix design of M40 grade concrete with water/cement ratio 0.4, Mix contents of varying fibers Polypropylene with a mixing ratio of $0 \%$ to $1.5 \%$ with intervals of $0.5 \%$ by volume were used, Super plasticizer $0.8 \%$, Portable cement $425\left(\mathrm{~kg} / \mathrm{m}^{3}\right)$, M-sand and coarse aggregate $705 \mathrm{~kg} / \mathrm{m}^{3}$ and $1090 \mathrm{~kg} / \mathrm{m}^{3}$ were also used for Slump of $75 \mathrm{~mm}$. The design mix proportions of Concrete were determined. The materials proportions of the High-performance SCC with addition of fly ash and Polypropylene fibers with fresh concrete properties (EFNARC) are shown in Table 5-8 and tested of harden concrete according to codal provision $[13,14]$. 
Table 5. Design Mix Proportions with addition of fly ash and PP (Normal SCC)

\begin{tabular}{|c|c|c|c|c|}
\hline \multirow{2}{*}{ Items } & \multicolumn{4}{|c|}{ concrete Mix Number } \\
\cline { 2 - 5 } & PM 0 & $\begin{array}{c}\text { PM } \\
\mathbf{0 . 5}\end{array}$ & $\begin{array}{c}\text { PM } \\
\mathbf{1 . 0}\end{array}$ & $\begin{array}{c}\text { PM } \\
\mathbf{1 . 5}\end{array}$ \\
\hline Cement $\left(\mathrm{Kg} / \mathrm{m}^{3}\right)$ & 410 & 410 & 410 & 410 \\
\hline Fly ash $\left(\mathrm{Kg} / \mathrm{m}^{3}\right)$ & 222 & 222 & 222 & 222 \\
\hline Fine aggregate $\left(\mathrm{Kg} / \mathrm{m}^{3}\right)$ & 640 & 640 & 640 & 640 \\
\hline $\begin{array}{c}\text { Coarse Aggregate } \\
\left(\mathrm{Kg} / \mathrm{m}^{3}\right)\end{array}$ & 830 & 830 & 830 & 830 \\
\hline Water $\left(\mathrm{Kg} / \mathrm{m}^{3}\right)$ & 185 & 185 & 185 & 185 \\
\hline Super Plasticizer $(\%)$ & 0.80 & 0.80 & 0.80 & 0.80 \\
\hline Polypropylene fibers $(\%)$ & 0 & 0.5 & 1 & 1.5 \\
\hline W/P (ratio) & 0.45 & 0.45 & 0.45 & 0.45 \\
\hline Slump Flow(mm) & 720 & 710 & 705 & 690 \\
\hline T50(Sec) & 2.8 & 2.8 & 2.6 & 2.5 \\
\hline V funnel test (Sec) & 8.2 & 8.2 & 8.4 & 8.5 \\
\hline $\begin{array}{c}\text { Compressive strength } \\
\left(\mathrm{N} / \mathrm{mm}^{2}\right)\end{array}$ & 45.2 & 46.4 & 48.8 & 46.8 \\
\hline $\begin{array}{c}\text { Split tensile strength } \\
\left(\mathrm{N} / \mathrm{mm}^{2}\right)\end{array}$ & 5.10 & 5.25 & 5.40 & 5.28 \\
\hline Flexural strength (N/mm $\left.{ }^{2}\right)$ & 7.25 & 7.42 & 8.10 & 7.48 \\
\hline
\end{tabular}

Table 6. Design Mix Proportions with addition of fly ash and PP (20\% fly ash replacement)

\begin{tabular}{|c|c|c|c|c|}
\hline \multirow{2}{*}{ Items } & \multicolumn{4}{|c|}{ concrete Mix Number } \\
\cline { 2 - 5 } & PM 0 & $\begin{array}{c}\text { PM } \\
\mathbf{0 . 5}\end{array}$ & $\begin{array}{c}\text { PM } \\
\mathbf{1 . 0}\end{array}$ & $\begin{array}{c}\text { PM } \\
\mathbf{1 . 5}\end{array}$ \\
\hline Cement $\left(\mathrm{Kg} / \mathrm{m}^{3}\right)$ & 328 & 328 & 328 & 328 \\
\hline Fly ash $\left(\mathrm{Kg} / \mathrm{m}^{3}\right)$ & 304 & 304 & 304 & 304 \\
\hline Fine aggregate $\left(\mathrm{Kg} / \mathrm{m}^{3}\right)$ & 640 & 640 & 640 & 640 \\
\hline $\begin{array}{c}\text { Coarse Aggregate } \\
\left(\mathrm{Kg} / \mathrm{m}^{3}\right)\end{array}$ & 830 & 830 & 830 & 830 \\
\hline Water $\left(\mathrm{Kg} / \mathrm{m}^{3}\right)$ & 185 & 185 & 185 & 185 \\
\hline Super Plasticizer $(\%)$ & 0.80 & 0.80 & 0.80 & 0.80 \\
\hline Polypropylene fibers $(\%)$ & 0 & 0.5 & 1 & 1.5 \\
\hline W/P (ratio) & 0.45 & 0.45 & 0.45 & 0.45 \\
\hline Slump Flow(mm) & 740 & 740 & 730 & 725 \\
\hline T50(Sec) & 2.6 & 2.5 & 2.45 & 2.4 \\
\hline V funnel test (Sec) & 8.00 & 8.10 & 8.2 & 8.25 \\
\hline $\begin{array}{c}\text { Compressive strength } \\
\left(\mathrm{N} / \mathrm{mm}^{2}\right)\end{array}$ & 47.2 & 48.6 & 49.9 & 48.7 \\
\hline $\begin{array}{c}\text { Split tensile strength } \\
\left(\mathrm{N} / \mathrm{mm}^{2}\right)\end{array}$ & 5.42 & 5.68 & 6.1 & 5.70 \\
\hline Flexural strength (N/mm $\left.{ }^{2}\right)$ & 7.52 & 7.92 & 8.92 & 8.1 \\
\hline
\end{tabular}

Table 7. Design Mix Proportions with addition of fly ash and PP (40\% fly ash replacement)

\begin{tabular}{|c|c|c|c|c|}
\hline \multirow{2}{*}{ Items } & \multicolumn{4}{|c|}{ concrete Mix Number } \\
\cline { 2 - 5 } & PM 0 & $\begin{array}{c}\text { PM } \\
\mathbf{0 . 5}\end{array}$ & $\begin{array}{c}\text { PM } \\
\mathbf{1 . 0}\end{array}$ & $\begin{array}{c}\text { PM } \\
\mathbf{1 . 5}\end{array}$ \\
\hline Cement $\left(\mathrm{Kg} / \mathrm{m}^{3}\right)$ & 246 & 246 & 246 & 246 \\
\hline Fly ash $\left(\mathrm{Kg} / \mathrm{m}^{3}\right)$ & 386 & 386 & 386 & 386 \\
\hline Fine aggregate $\left(\mathrm{Kg} / \mathrm{m}^{3}\right)$ & 640 & 640 & 640 & 640 \\
\hline $\begin{array}{c}\text { Coarse Aggregate } \\
\left(\mathrm{Kg} / \mathrm{m}^{3}\right)\end{array}$ & 830 & 830 & 830 & 830 \\
\hline Water $\left(\mathrm{Kg} / \mathrm{m}^{3}\right)$ & 185 & 185 & 185 & 185 \\
\hline Super Plasticizer $(\%)$ & 0.80 & 0.80 & 0.80 & 0.80 \\
\hline Polypropylene fibers $(\%)$ & 0 & 0.5 & 1 & 1.5 \\
\hline W/P (ratio) & 0.45 & 0.45 & 0.45 & 0.45 \\
\hline Slump Flow(mm) & 760 & 750 & 735 & 730 \\
\hline T50(Sec) & 2.35 & 2.4 & 2.5 & 2.55 \\
\hline V funnel test $($ Sec $)$ & 7.2 & 7.3 & 7.45 & 7.5 \\
\hline $\begin{array}{c}\text { Compressive strength } \\
\left(\mathrm{N} / \mathrm{mm}^{2}\right)\end{array}$ & 49.1 & 50.4 & 52.8 & 49.8 \\
\hline $\begin{array}{c}\text { Split tensile strength } \\
\left(\mathrm{N} / \mathrm{mm}^{2}\right)\end{array}$ & 6.15 & 6.92 & 7.2 & 6.20 \\
\hline Flexural strength (N/mm $\left.{ }^{2}\right)$ & 8.95 & 9.4 & 9.85 & 8.9 \\
\hline
\end{tabular}

Table 8. Design Mix Proportions with addition of fly ash and PP (60\% fly ash replacement)

\begin{tabular}{|c|c|c|c|c|}
\hline \multirow{2}{*}{ Items } & \multicolumn{4}{|c|}{ concrete Mix Number } \\
\cline { 2 - 5 } & $\begin{array}{c}\text { PM } \\
\mathbf{0}\end{array}$ & $\begin{array}{c}\text { PM } \\
\mathbf{0 . 5}\end{array}$ & $\begin{array}{c}\text { PM } \\
\mathbf{1 . 0}\end{array}$ & $\begin{array}{c}\text { PM } \\
\mathbf{1 . 5}\end{array}$ \\
\hline Cement $\left(\mathrm{Kg} / \mathrm{m}^{3}\right)$ & 164 & 164 & 164 & 164 \\
\hline Fly ash $\left(\mathrm{Kg} / \mathrm{m}^{3}\right)$ & 468 & 468 & 468 & 468 \\
\hline Fine aggregate $\left(\mathrm{Kg} / \mathrm{m}^{3}\right)$ & 640 & 640 & 640 & 640 \\
\hline Coarse Aggregate $\left(\mathrm{Kg} / \mathrm{m}^{3}\right)$ & 830 & 830 & 830 & 830 \\
\hline Water $\left(\mathrm{Kg} / \mathrm{m}^{3}\right)$ & 185 & 185 & 185 & 185 \\
\hline Super Plasticizer $(\%)$ & 0.80 & 0.80 & 0.80 & 0.80 \\
\hline Polypropylene fibers $(\%)$ & 0 & 0.5 & 1 & 1.5 \\
\hline W/P $($ ratio $)$ & 0.45 & 0.45 & 0.45 & 0.45 \\
\hline Slump Flow $(\mathrm{mm})$ & 790 & 780 & 770 & 765 \\
\hline T50(Sec) & 2.2 & 2.3 & 2.4 & 2.45 \\
\hline V funnel test $(\mathrm{Sec})$ & 6.8 & 6.9 & 7.0 & 7.1 \\
\hline $\begin{array}{c}\text { Compressive strength } \\
\left(\mathrm{N} / \mathrm{mm}^{2}\right)\end{array}$ & 47.4 & 48.2 & 50.1 & 48.8 \\
\hline $\begin{array}{c}\text { Split tensile strength } \\
\left(\mathrm{N} / \mathrm{mm}^{2}\right)\end{array}$ & 5.5 & 5.62 & 6.85 & 5.72 \\
\hline Flexural strength (N/mm $\left.{ }^{2}\right)$ & 7.6 & 7.9 & 9.3 & 8.2 \\
\hline
\end{tabular}

The above table's values are represented in graphs and discussion in result $\&$ discussion below. 


\section{Results and Discussions}

\section{a). Compressive Strength test (CST)}

The compressive strength test (CST) for normal SCC and Fly ash Replace with varies \%of High-performance SCC for 28 days were conducted and shown in figure 1, The results show Compression Strength tests PM 0-PM1.5.

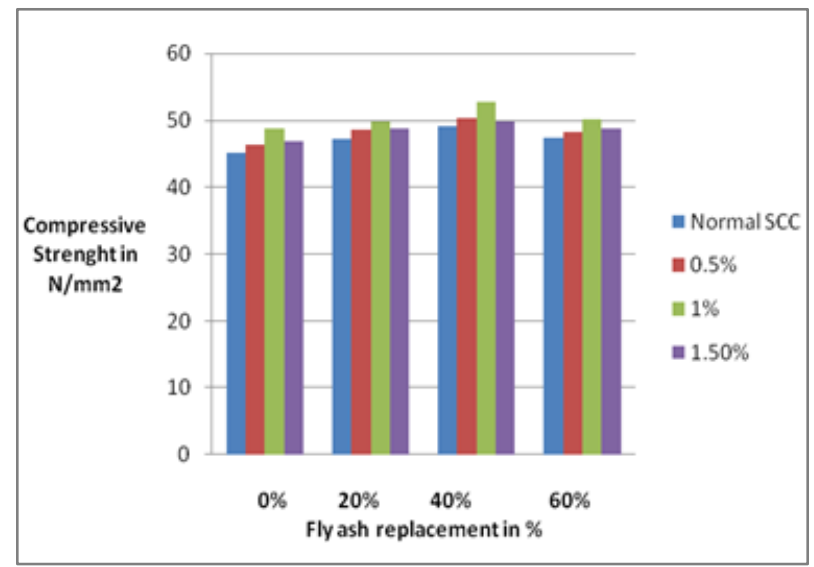

Figure 1. Compressive Strength testing Result of the Specimens

\section{b). Split tensile Strength test (STST)}

The Split tensile strength test (STST) for normal SCC and Fly ash Replace with varies \% of High-performance SCC for 28 days were conducted and shown in figure 2, The results show split tensile Strength tests PM 0-PM1.5.

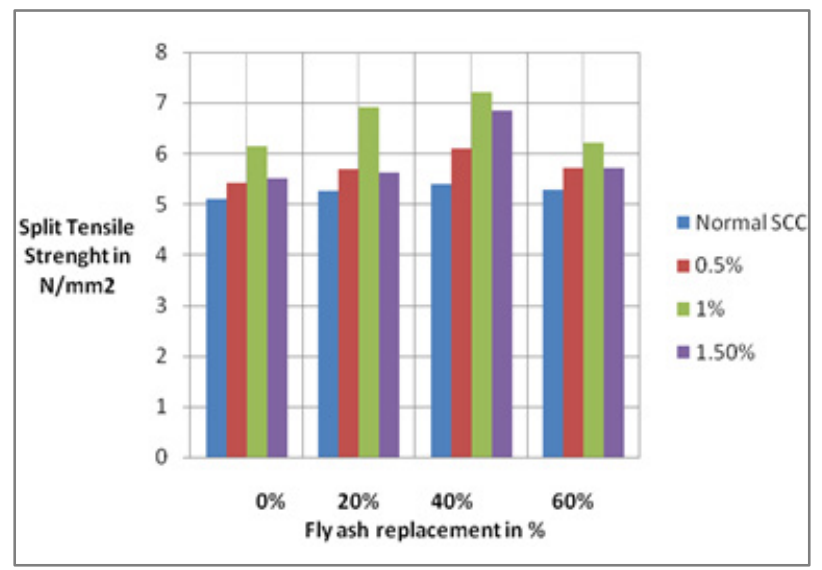

Figure 2. Split Tensile Strength Testing Result of the Specimens

\section{c). Flexural Strength test (FST)}

The flexural strength test (FST) for normal SCC and Fly ash Replace with varies \% of High-performance SCC for 28 days were conducted and show in figure 3, The results Shows flexural Strength tests PM 0-PM1.5.

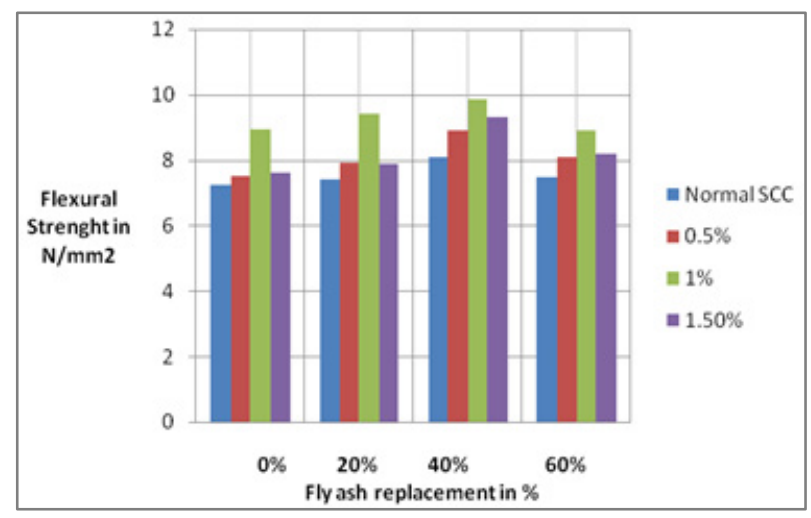

Figure 3. Flexural Strength testing Result of the Specimens

From the above figure showing in this investigation, the fiber percentage (\%) increases, the compressive, split tensile and flexural strength increases in all mix and also notice that strength increased by $1 \%$ fiber contents and $40 \%$ replacement of Fly ash in the mix. After adding fibers shows decreased in strength. The optimum fly ash is $40 \%$ replacements are observed maximum strengths.

\section{Conclusion}

In this investigation of the present work, the following points to be noticed based on Experimental work,

1. From this investigation shows that the addition of polypropylene fibers in high performance SCC gives homogeneous and mix of cohesive but decreases marginal workability.

2. The fresh properties of High-performance SCC concrete with fly ash satisfied the codal provisions recommendations with value.

3. The addition of fibers to the high-performance SCC concrete is increases the mechanical properties at $1 \%$ addition of polypropylene fibers attains the maximum strength.

4. From this study high performance SCC produced with $40 \%$ of fly ash with $1 \%$ of fiber addition.

5. Replacement of fly ash of class-F with Cement at a ratio of $40 \%$ is increases the hardened properties.

6. The addition $40 \%$ replacement of fly ash attains maximum compressive strength of $52.8 \mathrm{~N} / \mathrm{mm}^{2}$, Split tensile strength test of $7.2 \mathrm{~N} / \mathrm{mm}^{2}$ \& flexural strength of $9.85 \mathrm{~N} / \mathrm{mm}^{2}$

\section{Acknowledgements}

The authors would like to thank the Principal, Government Engineering College, Kushalnagar, India, for having provided experimental facilities in the Department of Civil Engineering to do this research work and also for the continuous support and encouragement given throughout this research work. 


\section{REFERENCES}

[1] B. Sandhya Rani, N. Priyanka, "Self-Compacting Concrete using Polypropylene Fibers" International Journal of Research Studies in Science, Engineering and Technology Volume 4, Issue 1, PP 16-19, 2017.

[2] Serin V Kurian, Sarah Anil, "Influence of Polypropylene Fiber in Self Compacting Concrete-A Review", Volume: 04 Issue: 05 |, ISSN: 2395-0072, 2017.

[3] K. S. Jhansirani and A. Jagannathan, "Studies on Effect of Mineral Admixtures on Durability of Self Compacting Concrete", European Journal of Advances in Engineering and Technology, Vol.2, pp. 87-94, 2015.

[4] Daniel C, Joel Shelton J, Vincent Sam Jebadurai S, Arun Raj E, "Studies on High Strength Self Compacting Concrete with Copper Slag for M30 grade", International Journal of Research in Engineering and Technology", Vol. 5, pp. 74-78,2016.

[5] B. Nagendra Kumar," Development of self-compacting concrete using quartz sand as an alternative of natural river sand" The India Concrete Journal Vol 91, pp. 43-50, 2018.

[6] T. Adhavanathan, V. Vinoth, "Experimental Investigation of

Self Compacting Concrete by using Copper Slag and Fly ash", International Journal for Scientific Research \& Development, Vol. 3, pp. 384-389, 2015.

[7] S. Girish, "Importance of volume of paste on the compressive strength of SCC - A parameter to be considered in mix design" The India Concrete Journal Vol 91, pp. 51-62, 2018.

[8] Indian standard code for ordinary Portland cement,53 Grade specification IS 12269-2013, Bureau of Indian Standards, New Delhi.

[9] Indian standard code for Methods of physical tests for hydraulic cement, IS 4031 (Part V)-1988, Bureau of Indian Standards, New Delhi.

[10] Indian standard code for Methods of test for pozzolanic materials, IS 1727:1967, Bureau of Indian Standards, New Delhi.

[11] Indian standard code for Methods of test for aggregates of concrete part I-IV IS: 2386-1963.

[12] Indian standard code for Methods of test for aggregates of concrete part I-IV IS: 2386-1963.

[13] Indian standard code for Methods of test for splitting tensile strength of concrete IS: 5816:1999

[14] Indian standard code for Methods of test for Strength of concrete IS: 516:2002 